\title{
Radiological Conditions on Rongelap Atoll: Perspective on Resettlement of Rongelap Atoll
}

\author{
T.F. Hamilton
}

February 20, 2003

U.S. Department of Enargy

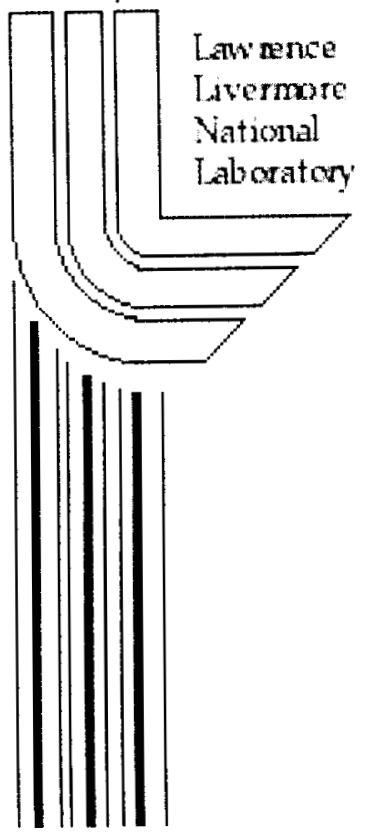




\section{DISCLAIMER}

This document was prepared as an account of work sponsored by an agency of the United States Government. Neither the United States Government nor the University of California nor any of their employees, makes any warranty, express or implied, or assumes any legal liability or responsibility for the accuracy, completeness, or usefulness of any information, apparatus, product, or process disclosed, or represents that its use would not infringe privately owned rights. Reference herein to any specific commercial product, process, or service by trade name, trademark, manufacturer, or otherwise, does not necessarily constitute or imply its endorsement, recommendation, or favoring by the United States Government or the University of California. The views and opinions of authors expressed herein do not necessarily state or reflect those of the United States Government or the University of California, and shall not be used for advertising or product endorsement purposes.

This work was performed under the auspices of the U.S. Department of Energy by the University of California, Lawrence Livermore National Laboratory under Contract No. W-7405-Eng-48.

This report has been reproduced directly from the best available copy.

Available electronically at http://www.doc.gov/bridge

Available for a processing fee to U.S. Department of Energy

And its contractors in paper from

U.S. Department of Energy

Office of Scientific and Technical Information

P.O. Box 62

Oak Ridge, TN 37831-0062

Telephone: (865) 576-8401

Facsimile: (865) 576-5728

E-mail: reports@adonis.osti.gov

Available for the sale to the public from

U.S. Department of Commerce

National Technical Information Service

5285 Port Royal Road

Springfield, VA 22161

Telephone: (800) 553-6847

Facsimile: (703) 605-6900

E-mail: orders@ntis.fedworld.gov

Online ordering: http://www.ntis.gov/ordering.htm

\section{OR}

Lawrence Livermore National Laboratory

Technical Information Department's Digital Library

http://www.llnl.gov/tid/Library.html 
Radiological Conditions on Rongelap Atoll

\section{Perspective on Resettlement of Rongelap Island}

The most widely accepted international guidelines for protection of the public from ionizing radiation and in circumstances related to intervention strategies to reduce exposures to preexisting conditions, such as those on Rongelap Island, come from the International Commission on Radiological Protection, the National Council on Radiation Protection and the International Atomic Energy Agency. By all internationally agreed scientific criteria, present radiological conditions on Rongelap Island are considered safe for permanent resettlement. Safe implies that no additional cancer deaths are expected among those living on Rongelap Island beyond the number that would occur in a community of the same population size, similar ages and mix of males and females, who do not experience exposure to residual fallout by living on the island. It is expected that the average dose received by Rongelap Island residents will fall well below the dose adopted by the Republic of the Marshall Islands' Nuclear Claims Tribunal considered a 'safe' or acceptable health risk. ${ }^{1}$ These conclusions are supported by environmental measurements and assessments performed by the Lawrence Livermore National Laboratory (LLNL) including the results of radiological surveillance of resettlement workers living on Rongelap Island for various lengths of time from 1999 through 2002, and independent studies conducted by Japanese scientists.

Atmospheric testing of nuclear weapons was responsible for the widespread dispersion of radioactive fallout around the globe. Rongelap Island received higher levels of fallout from local or close-in fallout deposition from nuclear testing on Bikini Atoll. The main pathway for exposure to radiation from the bomb testing is "internally" through ingestion of radioactive cesium (cesium-137) taken up from the soil into locally grown foodstuffs. Resettlement workers living on Rongelap Island who ate local foods have volunteered to have the cesium-137 content of their bodies measured. The measuring device is called a whole body counter. A person relaxes in a chair for a few minutes while counts are taken using a detector a few inches away from the body. The whole body counting program on Rongelap Island was established under a cooperative agreement between the Rongelap Atoll Local Government (RALG), the Republic of the Marshall Islands and the U.S. Department of Energy (DOE). Local technicians from Rongelap continue to operate the facility under supervision of scientists from LLNL.

Whole body counting data collected on resettlement workers during the initial phases of resettlement can tell us what exposure level a permanently resettled population could reasonably expect. The average internal dose to resettlement workers from cesium-137 is less than $1 \mathrm{mrem}(0.01 \mathrm{mSv})$ per year. The highest individual dose observed over the last 3 -years was less than $4 \mathrm{mrem}(0.04 \mathrm{mSv})$ per year. The RALG-DOE resettlement support plan also calls for spreading potassium fertilizer across the agricultural areas to prevent the uptake of cesium-137 into plants. Fertilization will reduce the dietary intake of

\footnotetext{
${ }^{1}$ The Nuclear Claims Tribunal has adopted a dose standard of 15 mrem per year based on guidance provided by the U.S. Environmental Protection Agency (EPA) for cleanup of designated sites in the United States. A more widely accepted international standard for protection of members of the public is 100 mrem per year above background.
} 
UCRL-ID-

cesium-137 and reduce the dose to island residents. By 2004, over 70 percent of the cesium-137 deposition in soil from fallout in 1954 will have decayed to a non-radioactive substance. Over the next 10-20 years, more than one-half of the remaining cesium-137 in the soil and vegetation of the atoll islands will have disappeared by decay or washed out of the soil by rain. Removing some soil, applying crushed coral around living areas, and spreading potassium fertilizer across agricultural areas will reduce the level of radiation exposure in the resettled population to levels below those considered safe by the Nuclear Claims Tribunal and to levels well below those considered safe by the international scientific community.

Dr. Terry Hamilton

Lawrence Livermore National Laboratory 